\title{
45. AMERY GROUP RED BEDS IN PRYDZ BAY, ANTARCTICA ${ }^{1}$
}

\author{
Barbara H. Keating ${ }^{2}$ and Hideo Sakai ${ }^{3}$
}

\begin{abstract}
A thick sequence of continental red beds was drilled at ODP Site 740, on the continental margin of Antarctica. The red beds lack dateable fossils. Paleomagnetic studies were undertaken to establish the age of formation for these rocks. Many of the rocks sampled were found to be thermally remagnetized and yielded paleomagnetic inclinations similar to those of intrusive units within outcrops of red beds in Antarctica. Based upon the similarities in lithology, sequence of rock types, thickness, magnetic properties, and thermal histories, a correlation is made with the Amery Group of Permian age. Red beds of this group are exposed in the Prince Charles Mountains, inland of Prydz Bay.
\end{abstract}

\section{INTRODUCTION}

During Leg 119 of the Ocean Drilling Program (ODP), several holes were drilled on the continental margin of Antarctica. At Hole 740A, the hole nearest the shoreline (Fig. 1), continental red beds were recovered. Sedimentologic studies indicate that these red beds represent fluvial deposits. No fossils were found in the red bed unit, apart from undatable algal spores. The age was designated "unknown" (Barron, Larsen, et al., 1989), and subsequent fossil studies have not produced age constraints for this unit (Truswell, this volume). Thus, paleomagnetic studies were undertaken to estimate the age of the sequence. Correlations are made with nearby outcrops of the Amery Group on the basis of lithology and stratigraphy and supported by paleomagnetic correlations (including the inclination and polarity, the character of the secondary magnetization, as well as rock magnetic characteristics). An age of Permian is suggested for the red bed sequence cored at ODP Hole 740A.

\section{BACKGROUND}

Prydz Bay is located on the eastern Antarctic continental margin, seaward of the Lambert Graben and Prince Charles Mountains (Fig. 1). At Site $740 \mathrm{~A}, 56 \mathrm{~m}$ of glacial and glaciomarine overburden and $58 \mathrm{~m}$ of continental red beds were penetrated. Seismic-reflection profiles, collected as part of predrilling site surveys of the seaward-dipping sedimentary section at Prydz Bay, revealed the stratified sequence at Hole $740 \mathrm{~A}$ (Barron, Larsen, et al., 1989). Outcrops of rock formations updip from Hole 740A include a lithologically correlatable red bed unit on shore in the vicinity of Prydz Bay (McKelvey and Stephenson, 1990).

The outcrops of the red beds described by McKelvey and Stephenson (1990) occur in the Prince Charles Mountains and are drained by the Amery Ice Shelf system. The southern Prince Charles Mountains consist of numerous nunataks forming mountain fringes of the Lambert and Kaliningrad glaciers (Hofman, 1982). A complex of Archean to upper Proterozoic metamorphic rocks, locally intruded by granites and unconformably overlain by Permian sediments (Tingey, 1972), forms the mountains (Grew, 1982; Ravich and Fedorov, 1982). Upper Permian clastic sediments are present in exposures around Beaver Lake in

\footnotetext{
${ }^{1}$ Barron, J., Larsen, B., et al., 1991. Proc. ODP, Sci. Results, 119: College Station, TX (Ocean Drilling Program).

${ }^{2}$ Hawaii Institute of Geophysics, University of Hawaii, Honolulu, HI 96822, U.S.A.

${ }^{3}$ Department of Earth Sciences, Toyama University, Gofuku 3190, Toyama City 930 , Japan.
}

the northern Prince Charles Mountains (Crohn, 1959; Mond, 1972; Bennett and Taylor, 1972). These units were mapped by McKelvey and Stephenson (1990). At least $2000 \mathrm{~m}$ of upper Permian Amery Group conglomerates and sandstones is overlain by coal measures, dipping to the south-southeast at about $10^{\circ}$ to $20^{\circ}$. Drilling at Site 741 , which is roughly $25 \mathrm{~km}$ from Site 740 , cored $104 \mathrm{~m}$ of black shales, sandstones, and coal placed roughly $1500 \mathrm{~m}$ higher in the geologic section than the red beds of Hole 740A (Barron, Larsen, et al., 1989). The stratigraphic sequence and thickness found by ODP drilling in Prydz Bay are thus similar to those reported at Beaver Lake by McKelvey and Stephenson (1990), but because the sediments at Site 741 are of post-rift Early Cretaceous age according to Truswell (this volume), they are not equivalent stratigraphically to the lower Permian Amery sequence.

The Permian Amery Group is the only known in-situ Paleozoic sedimentary sequence in all of MacRobertson Land. The flora contained in these rocks are described by Kemp (1973) and White (1973). The correlation of these rocks with part of the Beacon Supergroup of western Antarctica was suggested by Mond (1972). Within the southern Prince Charles Mountains fine-grained red siltstone debris containing Glossopteris plant fossils like those found in the red beds of the Amery Group at Beaver Lake and the Beacon Supergroup elsewhere (Ruker, 1963; White, 1962) was recovered in a moraine.

The Amery sediments at Beaver Lake have been intruded by two geochemically distinct intrusive units. The red beds are intruded by alnoite sills and strongly altered alkaline mafic dikes. The chilled margins and calcite veins and coatings on joint surfaces in the sills extend into the surrounding strata. McKelvey and Stephenson (1990) reported only one K-Ar age of $110 \mathrm{Ma}$ (mid-Cretaceous). Red bed sequences, containing thick intrusive bodies that have baked adjoining sediments, have been recorded throughout Gondwanaland. The red beds are loosely dated as Devonian through Triassic. It is suggested that the red bed sequence drilled at Hole 740A corresponds to the Amery Group in the Prince Charles Mountains.

The paleolatitude results derived from this study are discussed in the framework of the Permian tectonic configuration of Gondwanaland. Low paleolatitudes were observed in the red beds from Hole 740A. The paleoinclinations are consistent with those observed from intrusives found within red bed sequences throughout Antarctica. Paleomagnetic studies conducted on the Beacon Supergroup red beds (Turnbull, 1959; Bull and Irving, 1960; Bull et al., 1962; Hamilton, 1965; Christoffel, 1981; Funaki, 1983; Sakai and Funaki, 1988) evidence that thermal alteration of the red beds is abundant and very similar in nature to that observed in ODP Hole 740A. 

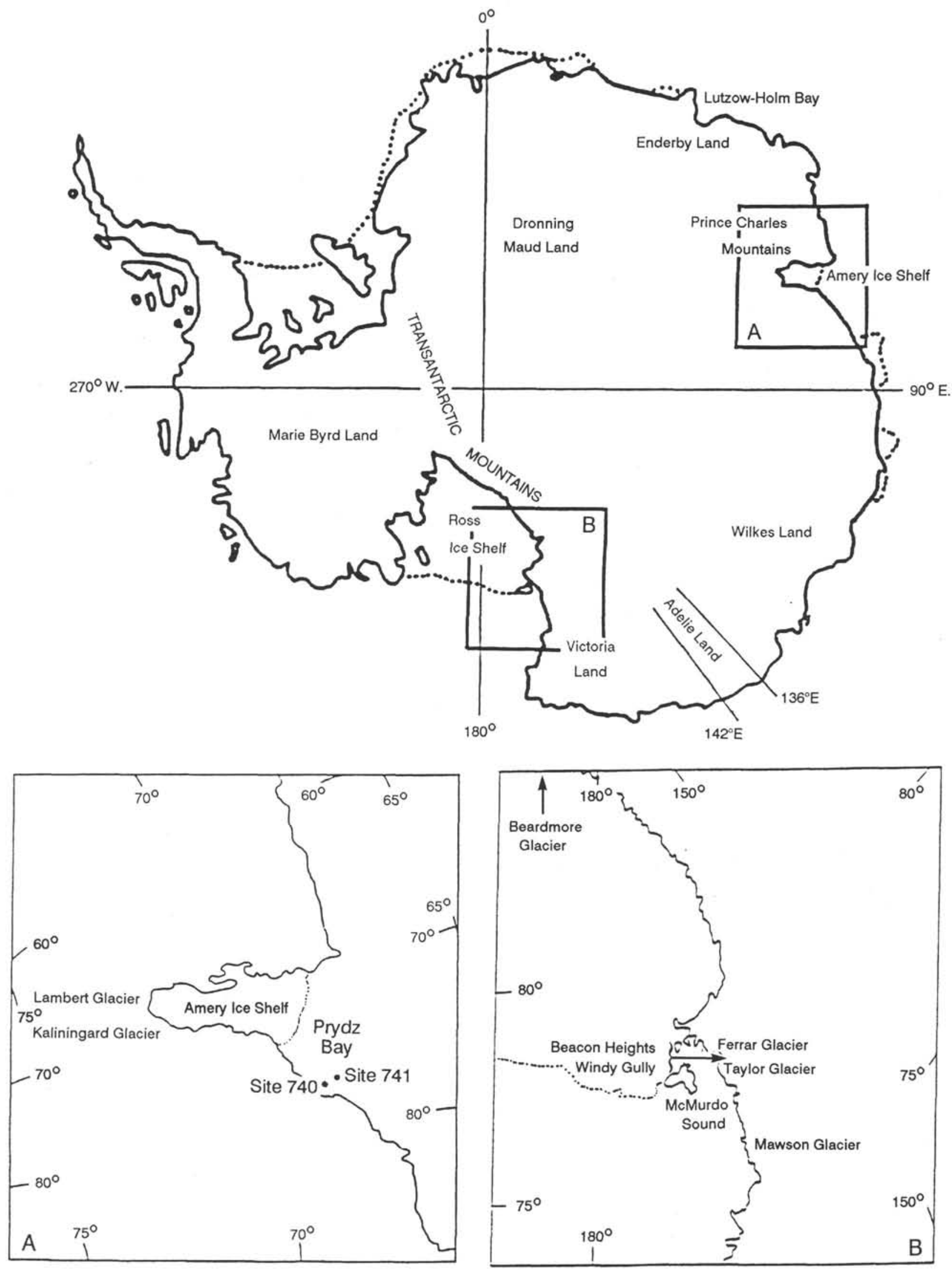

Figure 1. Map of Antarctica showing the location of (A) Sites 740 and 741 and (B) other paleomagnetic studies of Beacon Group sediments. 


\section{RED BEDS FROM HOLE 740A}

Turner (this volume) described the depositional environment and petrography of the red sediments from Hole $740 \mathrm{~A}$. The red sediments collected consist of $58 \mathrm{~m}$ of sandstone interbedded with siltstone and claystone. The siltstones and claystones represent fine-grained flood plain deposits. The numerous erosively based sequences observed are believed to represent sandy braided stream deposits. Discharge fluctuations in the braided streambeds were not great because significant amounts of trapped finegrained sediments occur throughout the sandstones. Turner concluded that much of the deposition of sandstones took place under steady-state flow conditions. Turner observed that pedogenic carbonate is absent other than in root structures and suggested that the climate may have been too wet for extensive calcrete formation.

Modal analysis of sandstones and siltstones indicates they are arkosic wackes composed of quartz, mica, and feldspar with subordinate rock fragments, garnet, and opaque minerals set in a clay matrix that makes up $17 \%-66 \%$ of the rock. Chlorite and sericite, some of diagenetic origin, are common constituents of the matrix. Turner (this volume) found in some thin sections that the matrix consists of a coarse mat of biotite, muscovite, sericite, and chlorite of medium-silt grade. Authigenic vermicular chlorite was also present in the matrix. In the more clay-rich sandstones the red sands are impregnated with iron oxides (mainly hematite). The green sandstones are rich in chlorite. Some quartz grains show poorly developed secondary overgrowths defined by a thin dust and iron oxide. The biotite grains are relatively fresh or show various stages of alteration, principally to hematite. Turner concluded that the sandstones were derived from a high-grade metamorphic terrain, namely the upper Proterozoic and Archaean gneisses of the Prydz Bay coast. The relatively fresh nature of most detrital grains is interpreted as evidence that, after deposition and burial took place, early diagenetic alteration and dissolution were limited.

\section{SUGGESTED CORRELATION WITH THE AMERY GROUP}

Red beds of the Amery Group are exposed at Beaver Lake, near Prydz Bay (Mond, 1972). The Amery Group consists of the Radok Conglomerate overlain by the Bainmedart Coal Measures and the Flagstone Beach Formation. The group is considered to be of late Permian age (Mond, 1972; Kemp, 1972, 1973). An early Permian age was assigned to the Radok Conglomerate by Ravich et al. (1977). The sediments were derived from the nearby late Proterozoic gneisses, granulites, and metasediments (Mond, 1972). The succession was deposited within a fluvial environment with a glacial influence on sedimentation (R. J. Tingey, in Stagg, 1985). McKelvey and Stephenson (1990) reported that the red beds at Beaver Lake have an unusual composition, with almost no plagioclase or pyroxene in the rocks. Turner (this volume) also reported that plagioclase and pyroxenes are absent in the red beds from Hole 740A. These observations help establish the geologic equivalence of these red bed units.

Truswell (1982) examined palynological material dredged from the seafloor off the east Antarctic coast, in the vicinity of Prydz Bay. The palynology studies identified Permian fossils indicative of well-vegetated alluvial plains. Truswell suggested that alluvial plains were extensively developed in eastern Antarctica during the Permian. The only fluvial sequences of this nature reported for eastern Antarctica are the outcrops of the Permian Amery Group.

Stagg (1985) examined seismic-reflection records from Prydz Bay and observed two seismic sequences separated by a mild erosional unconformity. The upper unit corresponds to the glacial and glaciomarine sediments drilled in the upper part of
Hole 740A. The lower unit is well stratified and corresponds to the lower part of the sequence in Hole 740A. Stagg (1985) argued that the only well-stratified sediments observed within the Prydz Bay area were the Permian red beds and suggested that the lower unit consisted of red beds similar to those in the Prince Charles Mountains.

\section{PALEOMAGNETIC STUDIES}

Paleomagnetic studies were undertaken in order to place constraints on the age of the red beds drilled at Hole 740A. The studies included detailed stepwise thermal demagnetization. Nearly 150 red bed samples were studied.

\section{Instrumentation and Laboratory Experiments}

The samples were inscribed with orientation lines prior to extraction from the core. The samples for this study consist of cubes cut from the lithified sediments using a rock saw and stored in plastic sample cubes. Generally, three samples were taken from each core section. Shipboard pilot studies were conducted using both alternating field demagnetization and thermal demagnetization; the thermal demagnetization studies suggested a complicated picture of multicomponent magnetization. Subsequent to the cruise, the samples were shipped to the University of Hawaii. The plastic sample cubes were opened so that the samples dried in air. The samples were labeled with white ink so that they could be identified after thermal demagnetization and were placed in a doubly shielded mu-metal room for 2 weeks prior to measurement. They were measured within the plastic sample boxes on a ScT three-axis superconducting magnetometer and demagnetized in groups of $12-18$ within a noninductively wound furnace in ambient atmosphere. The samples were cooled within a triple mu-metal shield (ambient field $0 \gamma \pm$ $5 \gamma$ ) and stored within the mu-metal-shielded work room throughout the experiment. Thermal demagnetization steps varied slightly from one container of samples to another, which is reflected in the list of temperatures displayed on the data plots. The temperatures ranged from room temperature to a maximum of $689^{\circ} \mathrm{C}$. A small group of samples proved friable and began to disintegrate at roughly $150^{\circ} \mathrm{C}$; thus, demagnetization was discontinued on these samples and the data from that small set of samples were not used in this study. Several of the coarser grained samples were omitted from thermal studies for this reason.

\section{Paleomagnetic Directions}

The red beds recovered at Hole $740 \mathrm{~A}$ were rotary cored and therefore are not azimuthally oriented. The tectonic and geologic correlations are based upon demagnetized inclination results. Furthermore, seismic-reflection records suggest that the beds dip roughly $15^{\circ}$ seaward. In theory the observed strike and dip could be used to structurally correct the paleomagnetic directions, so that full reorientation could be achieved. In practice, however, this has not happened. A request to measure the structural attitudes of the segments of core when the paleomagnetic samples were collected was declined by the Superintendent of the East Coast Repository, because the curatorial staff could not reliably produce these measurements, particularly for a large number of samples. As a result of deadlines for publication these measurements and subsequent corrections could not be made. Future plans call for measurement of the susceptibility anisotropy in the samples to determine orientation of the bedding plane as well as measurement of the strike and dip in the original cores at the repository in order to correct the paleomagnetic measurements for tilt.

At the present time, the core segments are not azimuthally oriented relative to each other, and the paleomagnetic samples were collected in a horizontal orientation but at a variety of azimuthal orientations relative to the bedding. The apparent dip is 
$15^{\circ}$, and structural corrections are needed to produce reliable paleoinclinations. Paleogeographic reconstructions, therefore, can only be discussed in a general way because these corrections are not now possible.

\section{Alternating Field Demagnetization}

The shipboard alternating field demagnetization studies were carried out on individual samples rather than on split-core sections. These samples were stepwise demagnetized to peak fields of $40 \mathrm{mT}$. The samples were measured on a Molspin magnetometer and demagnetized along three axes in a Schonstedt sample demagnetizer. The alternating field demagnetization proved ineffective in removing secondary components of magnetization from these samples. The inclinations remained steep with little decay in intensity after demagnetization to $40 \mathrm{mT}$. These experiments produced results similar to those from alternating field experiments on outcrop samples of the Beacon Supergroup sediments (Bull et al., 1962) and on igneous rocks that intrude the Beacon Supergroup (McIntosh et al., 1982).

\section{Thermal Demagnetization}

The magnetization history recorded in these rocks is complex. The demagnetization behavior of each of the samples was examined using orthogonal vector demagnetization diagrams, normalized demagnetization curves, and equal-angle stereonet projections showing the change in sample direction upon demagnetization. The sample demagnetization behavior falls into three general types (Fig. 2). One group of samples displays nearly linear decay of magnetization toward the origin of orthogonal plots and little change in magnetic directions, indicative of stable magnetization. A second group of samples has been remagnetized in a direction other than the original magnetization. A third group shows multiple components of magnetization.

A subset of samples within the multicomponent group displays such complex magnetization that an interpretation of the primary magnetization is considered unreliable. Samples within this group appear to be characterized by multiple components of magnetization having overlapping coercivity spectrums.

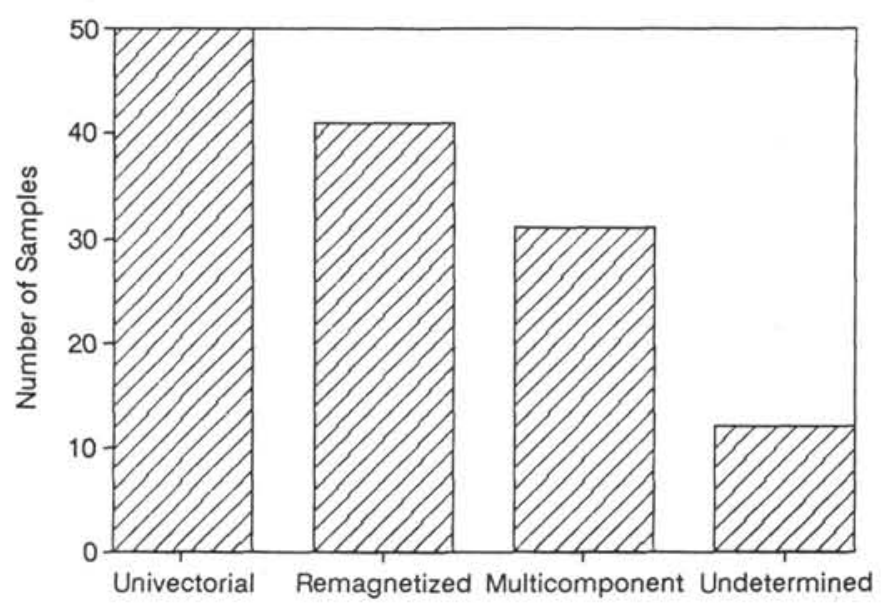

Figure 2. Histogram showing the frequency of occurrence of the major types of magnetic behavior observed in sediments from Hole 740A. Nearly linear decay of magnetization to the origin on orthogonal plots, referred to as "univectorial decay," occurs most frequently. Remagnetized samples and samples with multicomponents of magnetization have the next highest frequencies of occurrence, respectively. The few samples that display multiple components of magnetization and fail to reach end points have undetermined polarity and inclination.

\section{Univectorial Magnetization}

Many of the samples studied display univectorial decay of magnetization upon demagnetization. The samples show little change in sample direction of demagnetization, display moderate to steep inclinations, which average approximately $25^{\circ}$ after demagnetization (Fig. 3), and are all normally magnetized. This magnetization is the most stable magnetization observed.

A subset of samples displays nearly linear decay of magnetization toward the origin of the orthogonal plot (Fig. 4), but displays large changes in sample directions upon demagnetization. Initially they display very steep inclinations. After removal of the initial steep magnetization, the magnetization decays toward the center of the orthogonal plot (e.g., Sample 119-740A-8R-1, $40 \mathrm{~cm}$; Fig. 4) and the inclination becomes shallow. The natural remanent magnetization (NRM) inclinations average $76^{\circ}$ and are all negative, (i.e., normally magnetized in the Southern Hemisphere). The present Earth's field inclination at this site is $73^{\circ}$ (Peddie and Zunde, 1988). This component appears to be magnetization acquired in the present Earth's field because (1) the steep negative inclination corresponds with the present field inclination and (2) this is the first component removed upon demagnetization of the samples that display multiple components of magnetization.

\section{Remagnetized Samples}

A subset of samples displays a decay in magnetization upon demagnetization, but the direction changes do not trend toward the origin of the orthogonal plot but instead cluster around a direction other than the origin at elevated temperatures up to $645^{\circ} \mathrm{C}$ (Fig. 5). These samples reflect a stable remagnetization, probably resulting from heating associated with intrusive bodies. The mean inclination for this group is $24.9^{\circ}$.

\section{Multicomponent Magnetization}

The remainder of the samples from Hole 740A display multiple components of magnetization (Fig. 6). The demagnetization behavior can be described in terms of three groups. The largest group moves from normal polarity and steep inclinations to shallow normal polarity inclinations (e.g., Samples 119-740A$27 \mathrm{R}-5,46 \mathrm{~cm}$, and 119-740A-26R-3, $116 \mathrm{~cm}$; Fig. 6). A second group moves from steep inclinations of normal polarity to shallow inclinations of reversed polarity (e.g., Sample 119-740A$24 \mathrm{R}-1,146 \mathrm{~cm}$; Fig. 6). An examination of the thermal demagnetization curves shows that many of the samples in this group display significant increases in magnetization upon demagnetization. This secondary magnetization is of opposite polarity from the primary magnetization, and as the secondary component is removed the overall intensity rises. Apparently the samples have acquired a normal polarity thermal remanent magnetization that overprints the primary magnetization of reversed polarity and is removed at elevated temperatures.

A few samples move from steep reversed directions to shallow reversed directions (e.g., Sample 119-740A-28R-3, $33 \mathrm{~cm}$; Fig. 6) and a few samples move from reversed polarity to normal polarity. The distribution of samples in each group is shown in Figure 7. As the samples are demagnetized the inclinations become shallow or change to reversed polarity. The least stable magnetization is steep and of normal polarity and is interpreted as the present Earth's field direction. At high temperatures, the samples display shallow inclinations (averaging $24.7^{\circ}$ ). The thermal overprint is normal polarity in most cases, but there are isolated cases of reversed polarity overprints (Fig. 7). Both normal and reversed polarity primary magnetizations are present. 


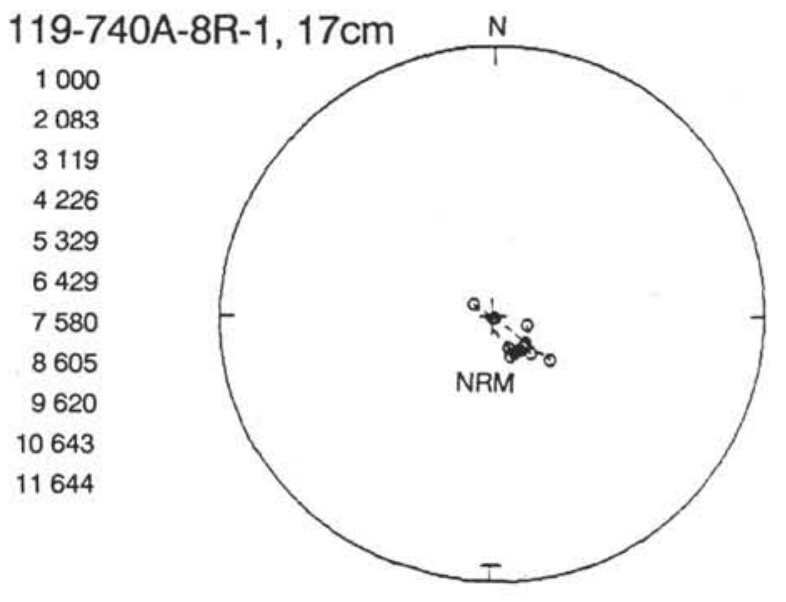

119-740A-8R-1, 17cm

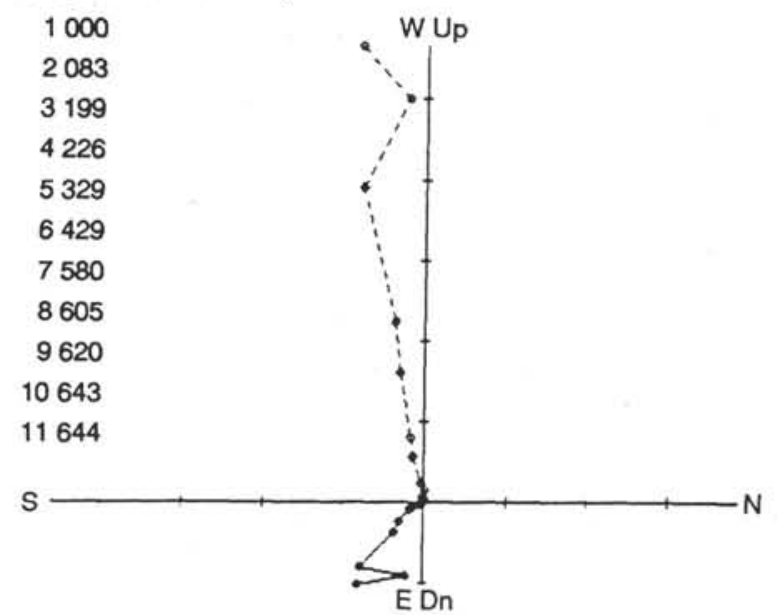

119-740A-28R-2, $105 \mathrm{~cm}$
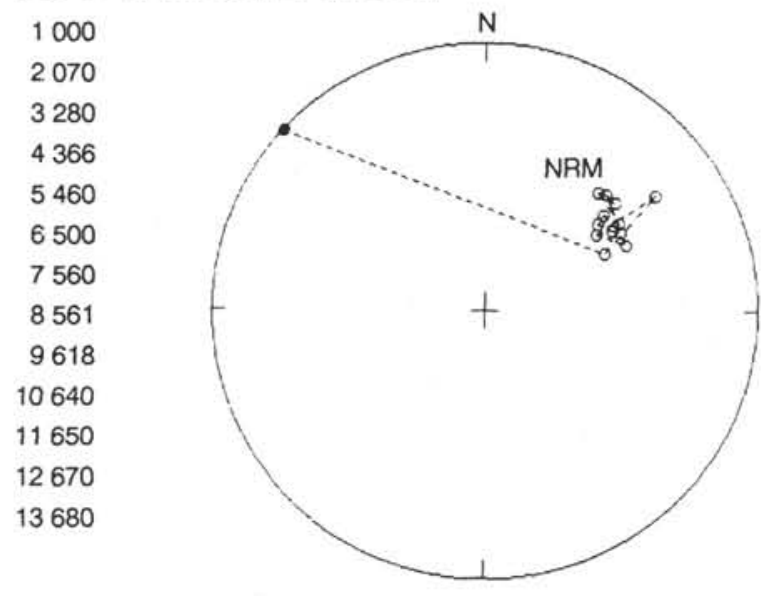

119-740A-28R-2, $105 \mathrm{~cm}$

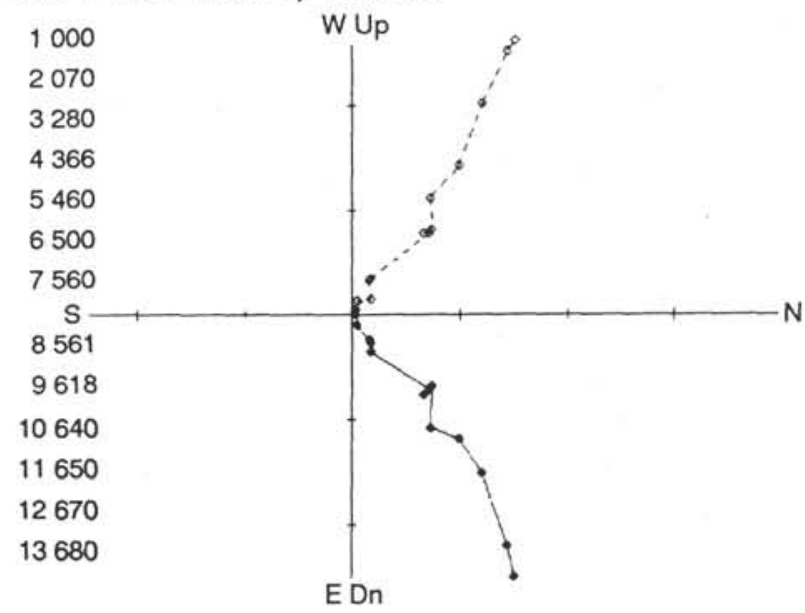

\section{9-740A-31R-5, 1cm}

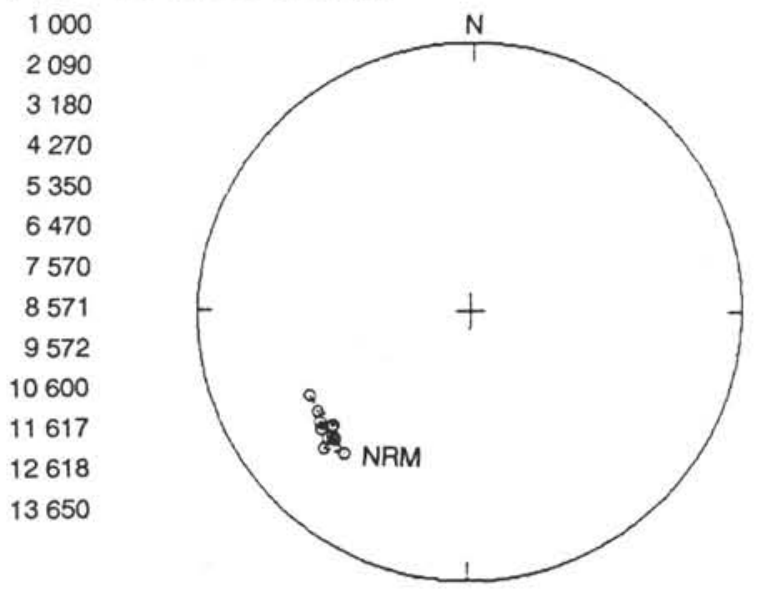

119-740A-31R-5, $1 \mathrm{~cm}$

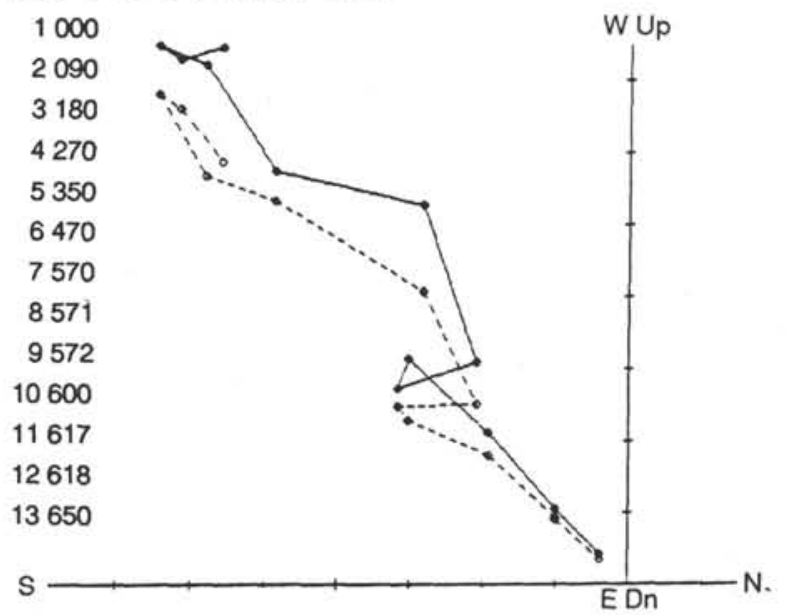

Figure 3. Equal-area stereonet projections and orthogonal plots of paleomagnetic directions for three samples from Hole 740A. The initial direction on the stereonet is labeled NRM; progressive thermal demagnetization steps are listed. Two of the samples appear to be magnetized in a very steep normal direction, which is interpreted as the present Earth's field direction. Sample 119-740A-28R-2, $105 \mathrm{~cm}$, displays a radical change in magnetic direction upon demagnetization at $680^{\circ} \mathrm{C}$; this behavior indicates that the sample has exceeded its critical blocking temperature and has acquired spurious magnetization during the measurement process. The orthogonal plots display near-univectorial decay of magnetization and very little change in sample direction upon demagnetization, except for Sample 119-740A-28R-2, $105 \mathrm{~cm}$, which has exceeded the critical blocking temperature. 
119-740A-8R-1, 40cm

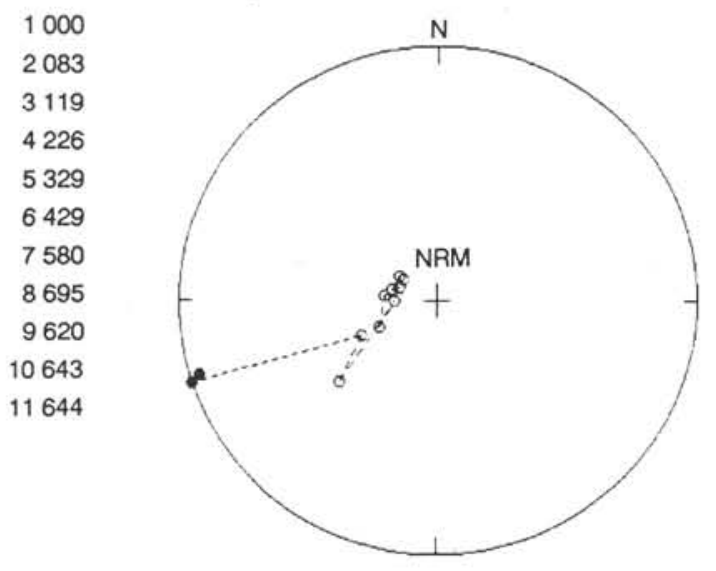

119-740A-28R-2, 46cm

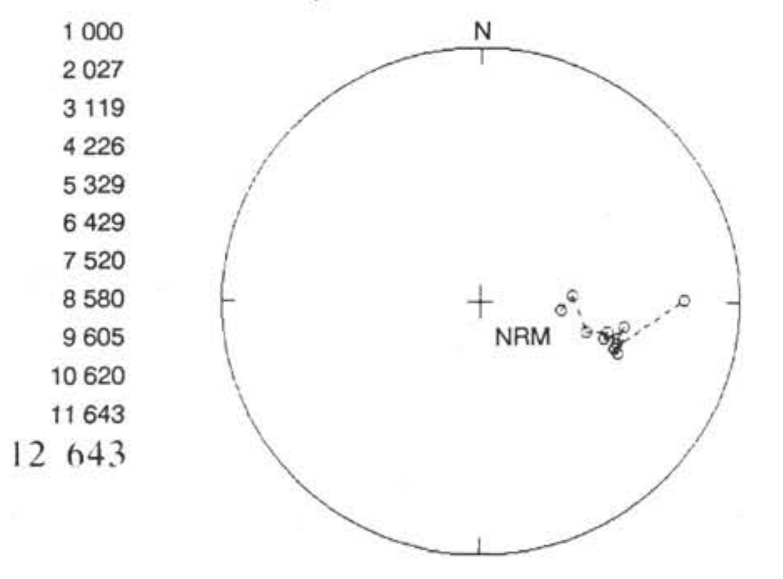

$119-740 \mathrm{~A}-31-3,148 \mathrm{~cm}$

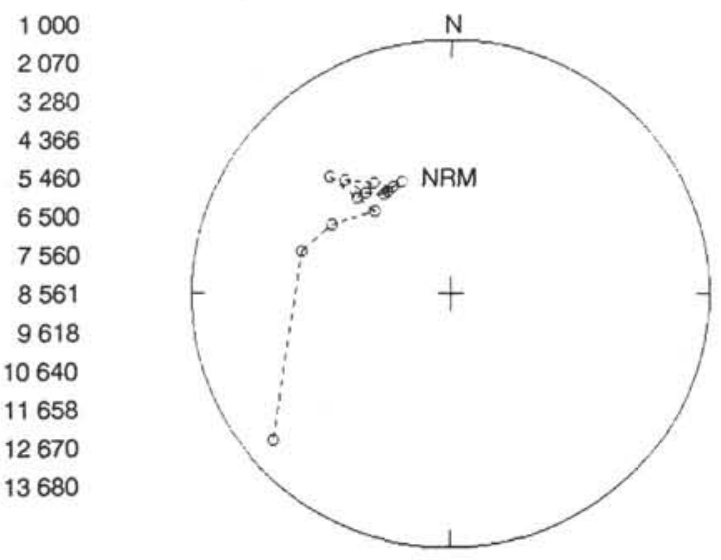

119-740A-8R-1, 40cm

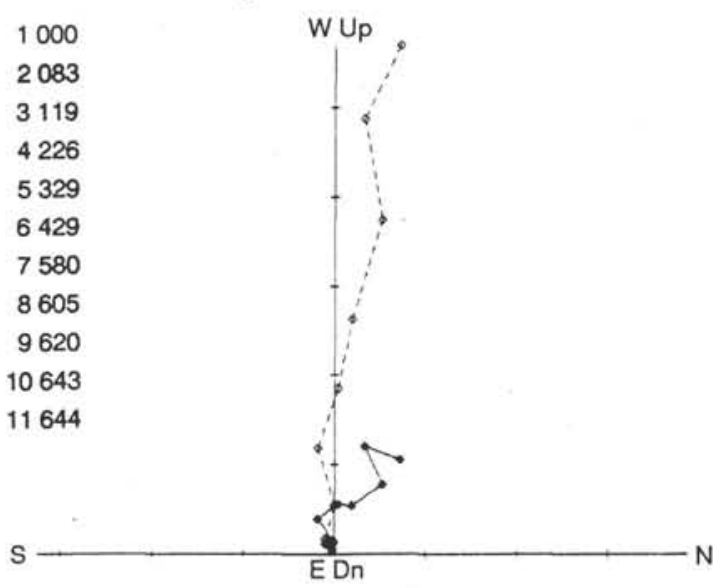

119-740A-28R-2, 46cm
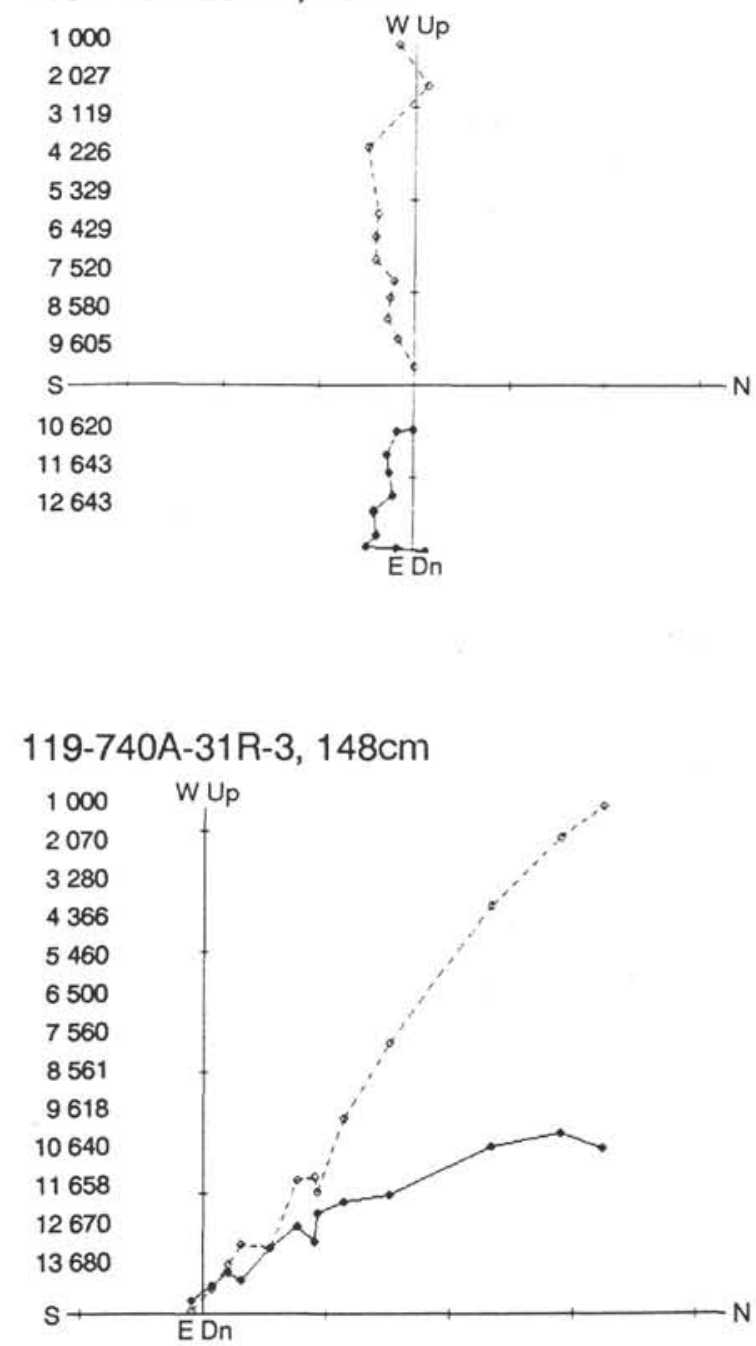

Figure 4. Equal-area stereonet projections and orthogonal plots of paleomagnetic directions for three samples from Hole 740A. The initial direction on the stereonet is labeled NRM; progressive thermal demagnetization steps are listed. These representative samples display a nearly univectorial decay but show significant changes in direction upon demagnetization. The steep NRM directions move progressively toward shallower inclinations upon thermal demagnetization. The end points display inclinations similar to those of stably magnetized samples interpreted as Jurassic remagnetization by other authors. These samples are interpreted as a stable Jurassic overprint of thermal origin. 
119-740A-14R-1, 32cm

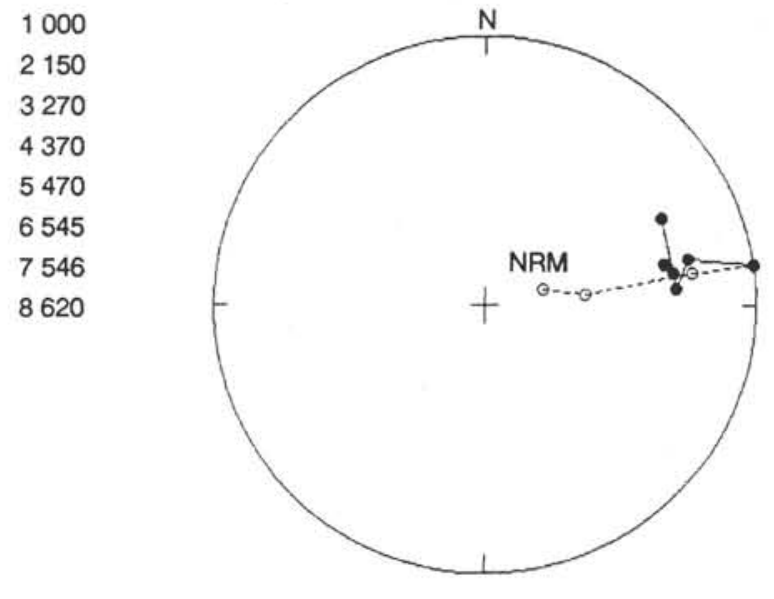

119-740A-20R-3, $146 \mathrm{~cm}$

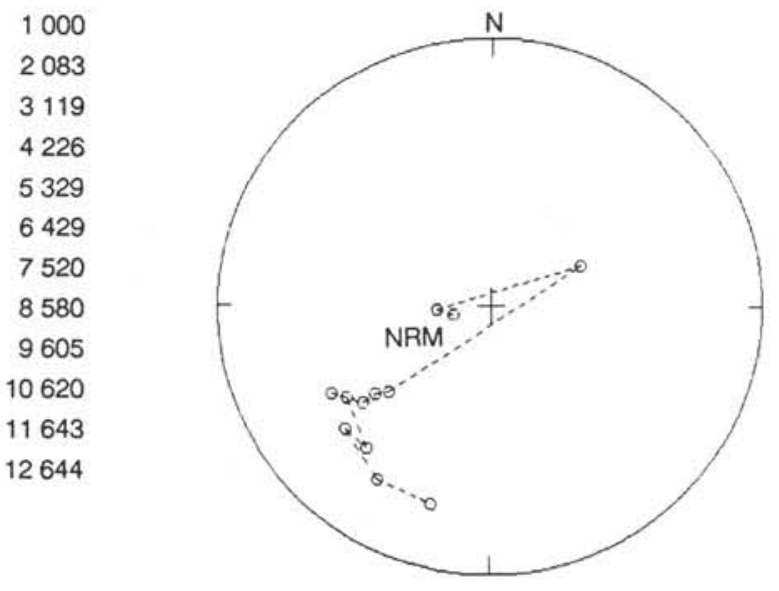

119-740A-22R-2, 3cm

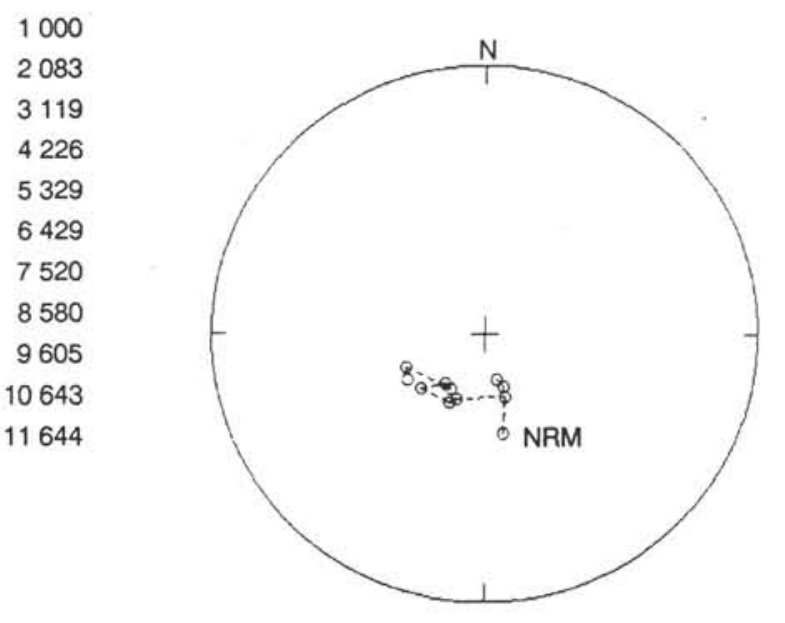

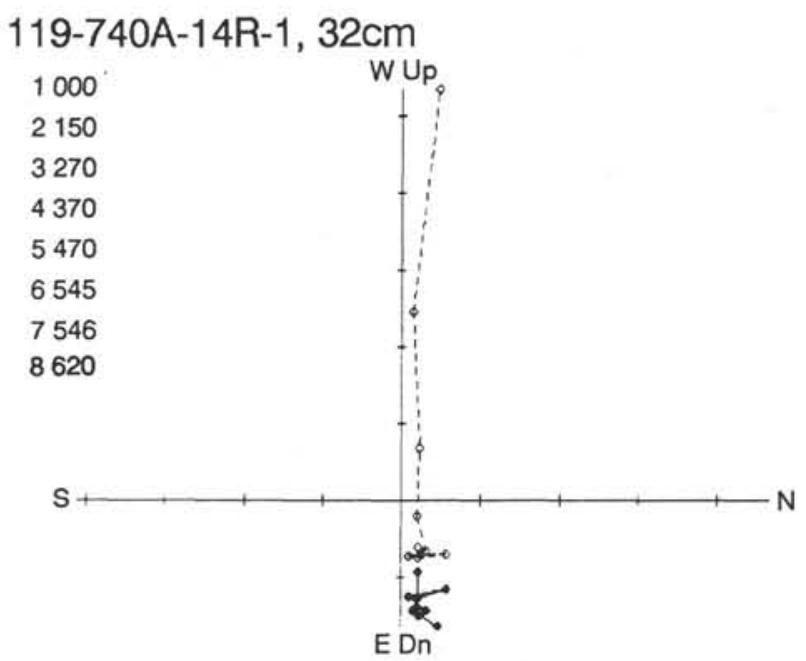

119-740A-20R-3, $146 \mathrm{~cm}$

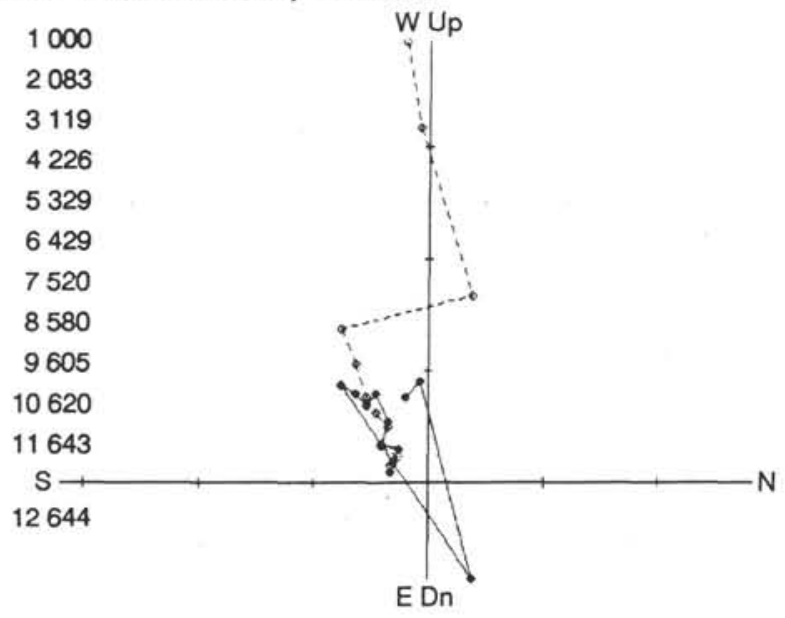

119-740A-22R-2, 3cm

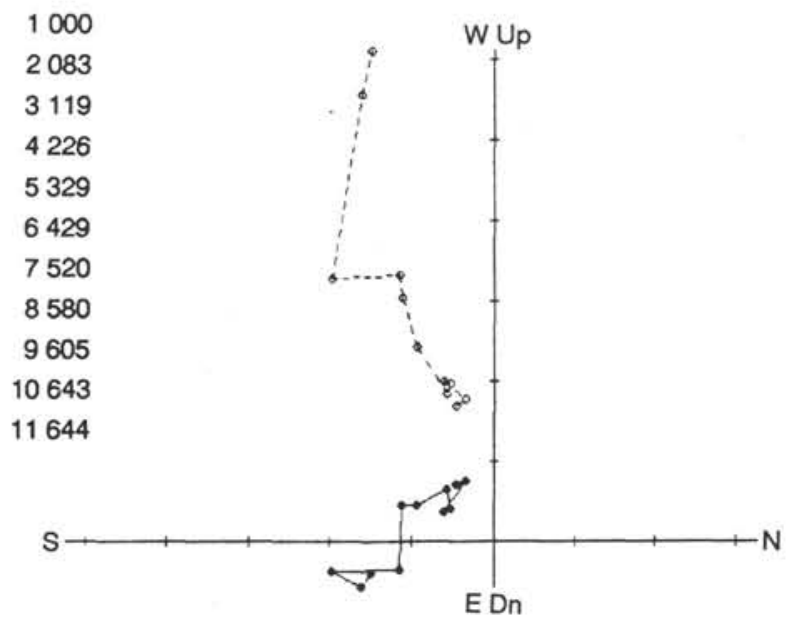

Figure 5. Equal-area stereonet projections and orthogonal plots of paleomagnetic directions for samples from Hole 740A that are characterized by a stably magnetized cluster of directions of moderate inclination. The initial direction on the stereonet is labeled NRM; progressive thermal demagnetization steps are listed. The stable magnetization away from the origin of the orthogonal plots is indicative of remagnetization at temperatures up to $645^{\circ} \mathrm{C}$. 
119-740A-20R-3, $146 \mathrm{~cm}$

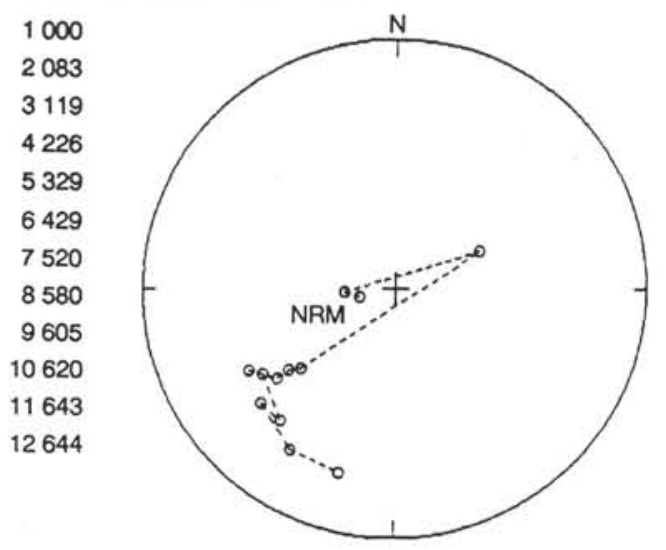

119-740A-26R-3, $116 \mathrm{~cm}$

1000
2070
3170
4280
5315
6366
7460
8560
9561
10562
11621
12640
13658
14670
15680
16689

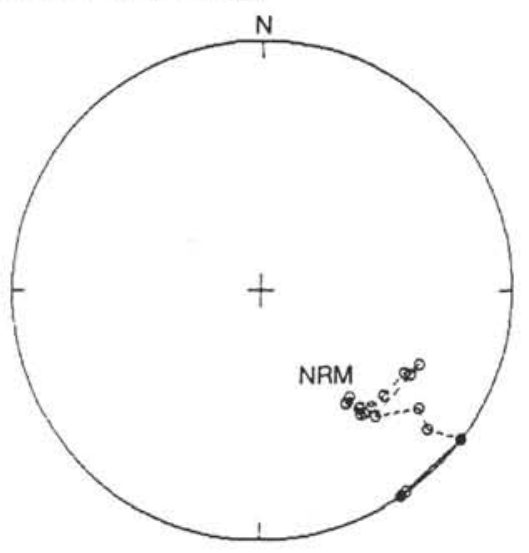

119-740A-24R-1, $146 \mathrm{~cm}$

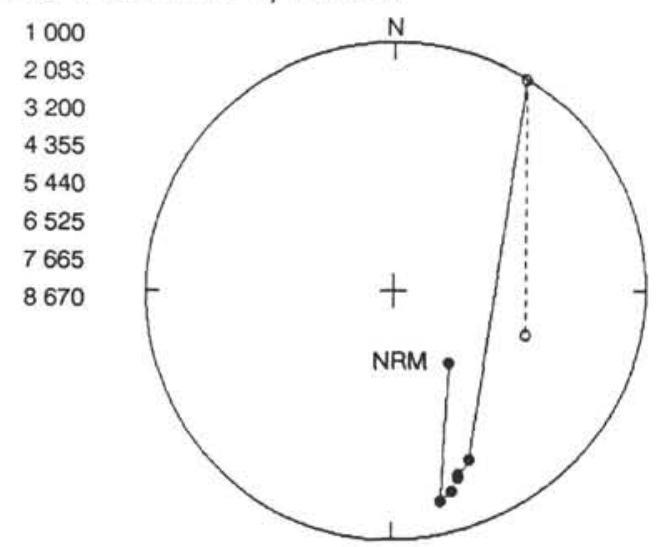

119-740A-20R-3, 146cm

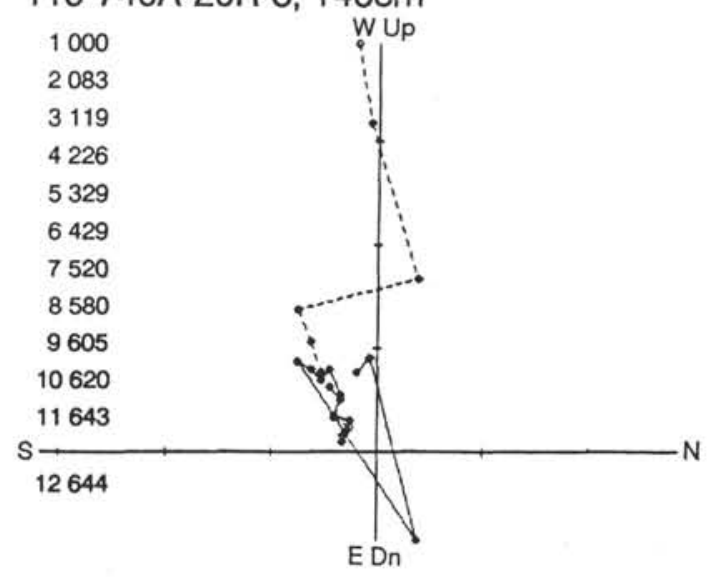

119- 740A-26R-3, $116 \mathrm{~cm}$

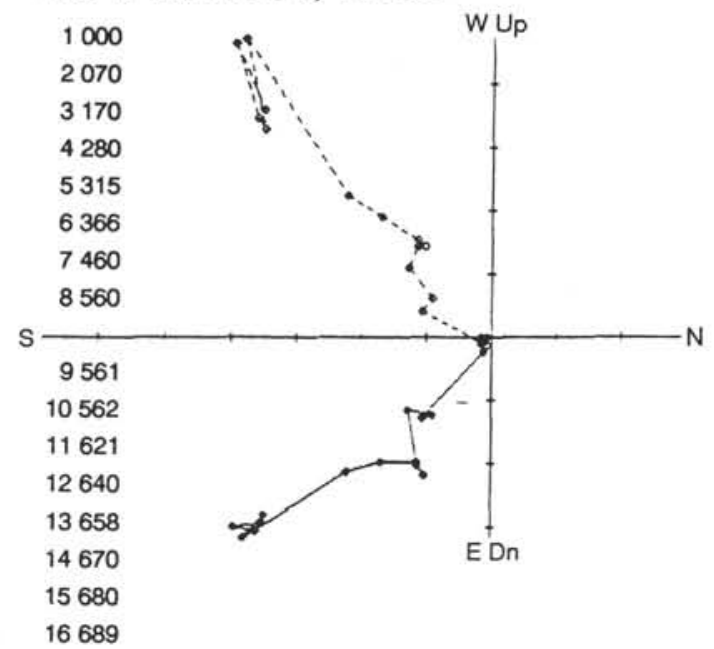

119-740A-24R-1, 146cm

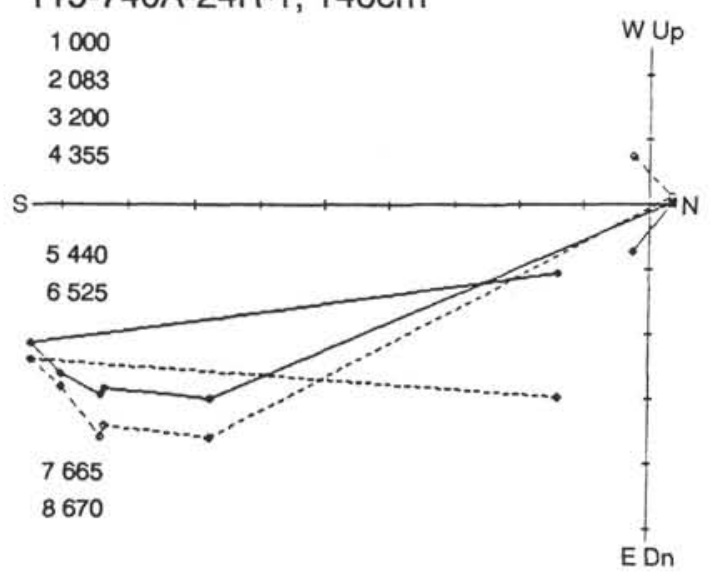

Figure 6. Equal-area stereonet projections and orthogonal plots of paleomagnetic directions for samples from Hole 740A that show a change in magnetization upon thermal demagnetization. The initial direction on the stereonet is labeled NRM; progressive thermal demagnetization steps are listed. Each sample displays multiple components of magnetization. The samples with reversely magnetized directions (solid symbols) of moderate inclination move upon demagnetization to shallow reversed directions or to normal directions (open symbols). The samples that switch polarity during demagnetization are classed as having undetermined polarity and inclination, because they do not reach stable end points. 
119-740A-25R-1, 90cm

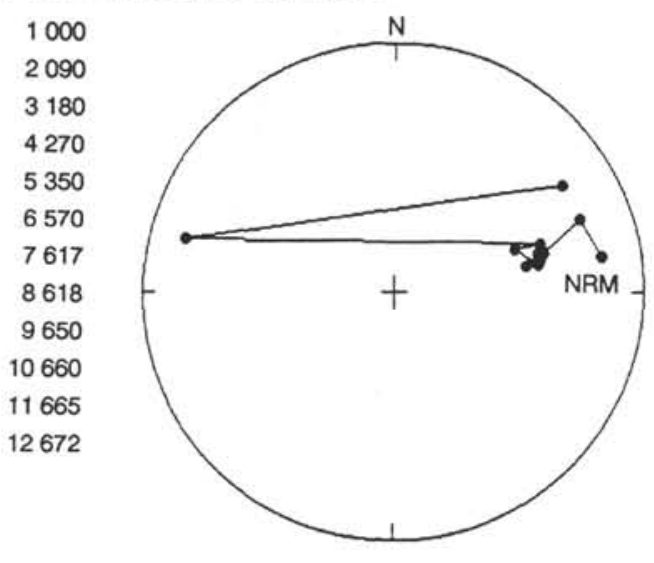

119-740A-25R-1, 3cm

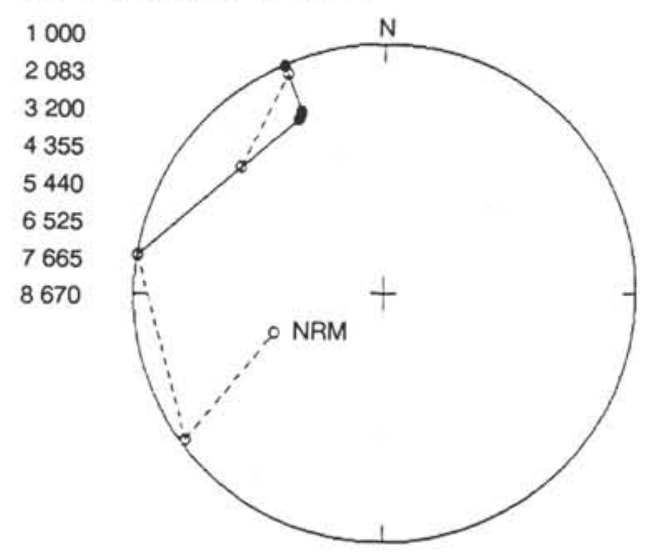

119-740A-28A-28R-3, 33cm

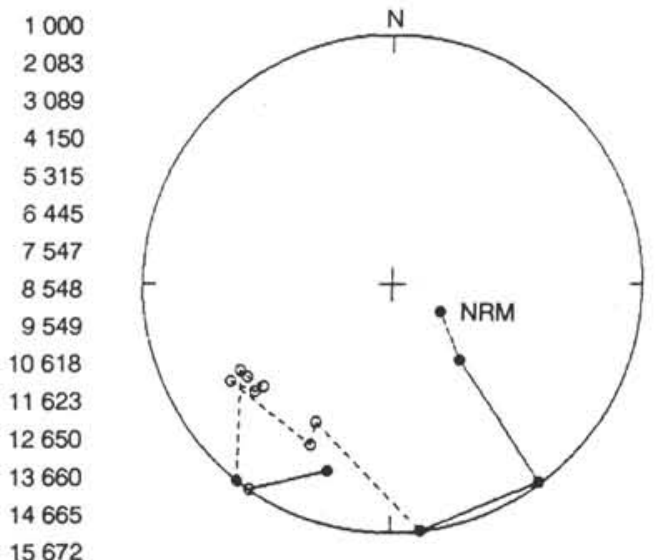

Figure 6 (continued).

\section{High-Temperature Magnetization}

Thermal demagnetization studies of the Hole $740 \mathrm{~A}$ red beds indicate that the critical blocking temperature exceeds $670^{\circ} \mathrm{C}$. Radical changes in magnetization direction occurred upon thermal demagnetization at temperatures of $680^{\circ}$ and $689^{\circ} \mathrm{C}$, indi-
119-740A-25R-1, $90 \mathrm{~cm}$

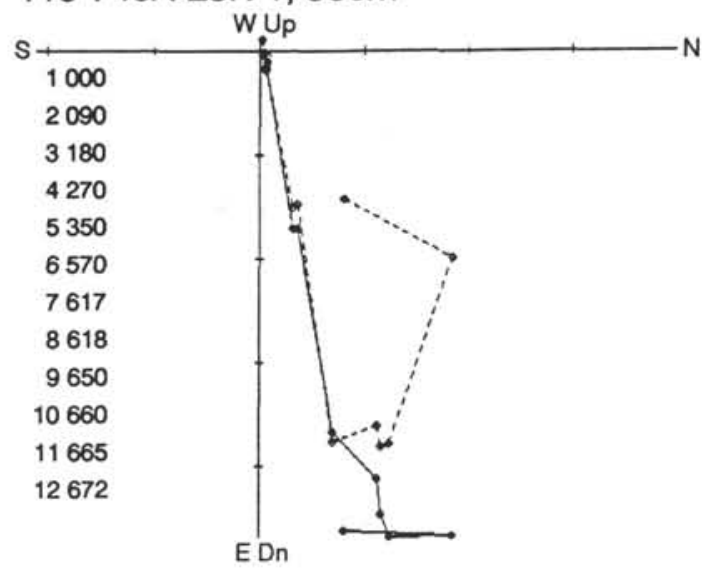

119-740A-25R-1, 3cm

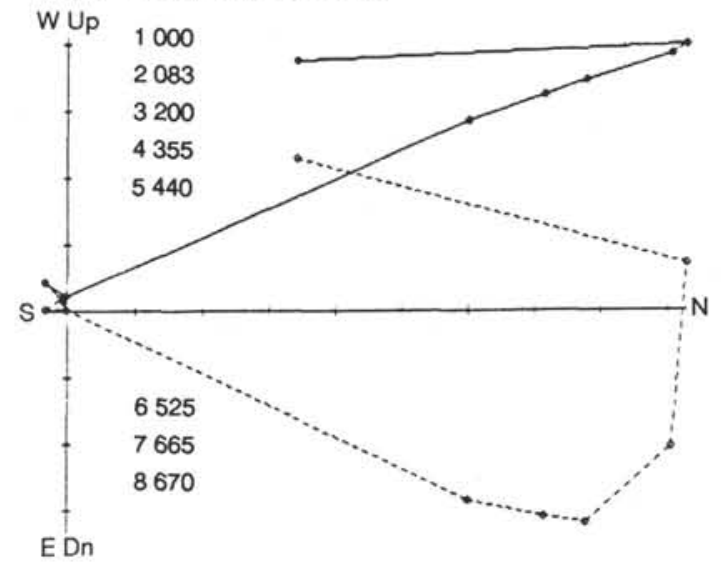

119-740A-28R-3, 33cm

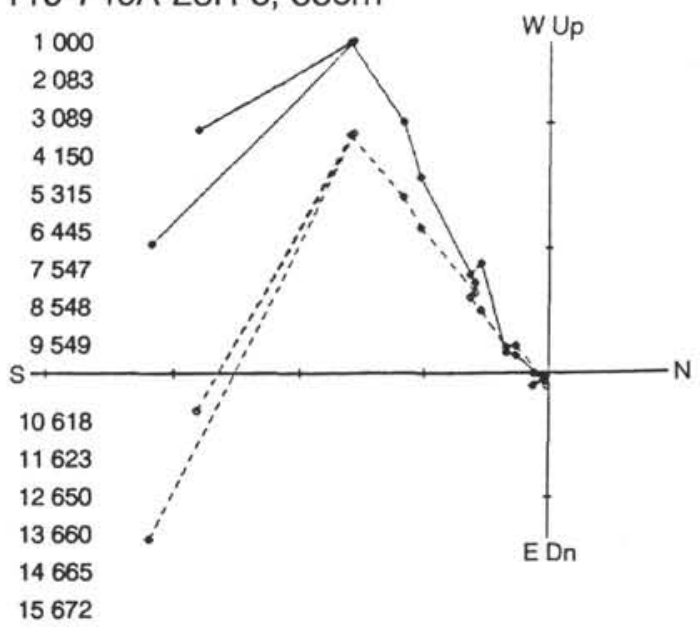

cating that many samples had been unblocked and acquired spurious magnetization at temperatures between $680^{\circ}$ and $689^{\circ} \mathrm{C}$. Prior studies of red beds of similar age from the Beacon Supergroup of western Antarctica also show that the thermal remanence remains strong to $660^{\circ} \mathrm{C}$. This is a high blocking temperature for red beds. Studies conducted in this laboratory of red 


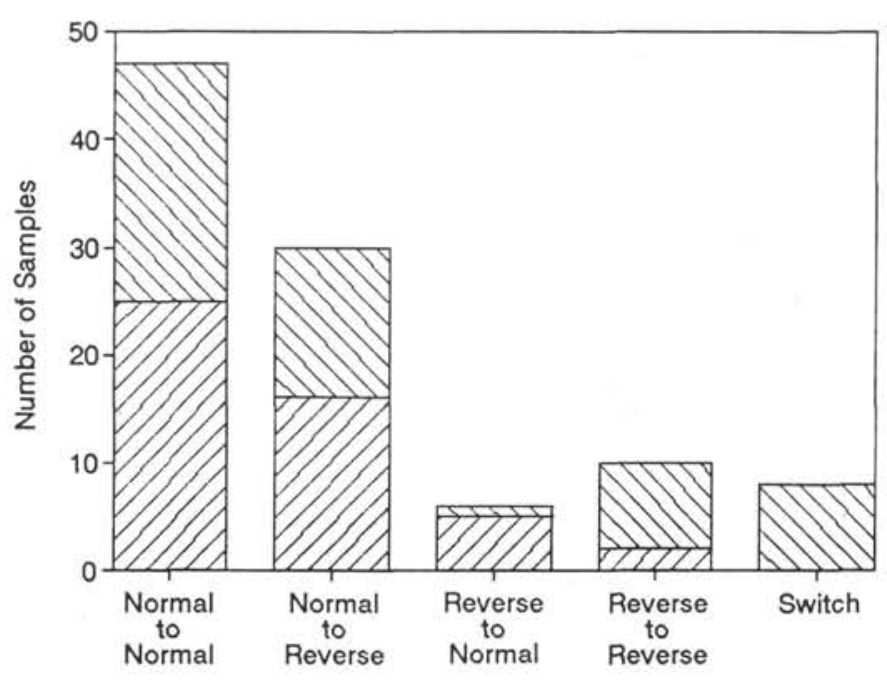

Figure 7. Histogram showing the trends in inclination on demagnetization. The largest group comprises samples with normal polarity NRM directions that remain normal on demagnetization. The second largest group consists of samples with normal NRM polarity directions that move to reversed polarity on demagnetization. Several samples have NRM directions that are initially reversed polarity, which indicates that the samples are characterized by mixed polarity. The samples that switch back and forth across the equator and do not stabilize at an end point are considered unstably magnetized. The lower part of the subdivided histogram bars indicates the number of samples displaying univectorial decay; the upper part of the bar represents the samples with multicomponent magnetization. The samples that switch polarity are all characterized by multicomponent magnetization.

beds of Permian through Jurassic age in North America generally reveal critical blocking temperatures of less than $600^{\circ} \mathrm{C}$; sporadic samples have critical blocking temperatures up to $630^{\circ} \mathrm{C}$. The higher critical blocking temperatures within the Beacon Supergroup are characteristic of that formation and are commonly associated with small grain size. The high critical blocking temperature is another useful magnetic characteristic for establishing a geological equivalence between the red beds of Hole 740A and the red beds of Antarctica.

\section{Intensity Changes}

The red beds in this study display a wide range of thermomagnetic remanence histories (Fig. 8). Roughly half of the demagnetization curves show increases in intensity, which are interpreted as arising from the removal of an overprint of an opposite polarity from that of the original magnetization. The variations in the magnitude of change and the shape of the curves indicate that the heating of the sediments was not uniform. Laboratory studies of the reheating effect of intrusive bodies on sedimentary rocks (e.g., Leng, 1955) show that direct heating decreases quickly away from an intrusion. Direct heating of the country rock by conduction from an igneous body is generally considered to be capable of resetting remanent magnetization as far away as one-fifth the dike width (Brown, 1981). Where the magnetic minerals have low Curie temperatures, remagnetization has been observed as far away as the dike width (Helgeson, 1981). The amount of heating depends on the size and temperature of the intrusive body, the thermal conductivity of the country rock, and the length of time the rocks spend at elevated temperatures. If fluids are associated with the intrusive and if the country rock is well insulated (e.g., burial is to a depth of $1 \mathrm{~km}$ or more), the effect of heating is much greater.
Within eastern Antarctica, the Amery red beds at Beaver Lake have been intruded by two compositionally different intrusive units, one forming sills and the other forming dikes. Deuteric alteration is extensive within the sills (McKelvey and Stephenson, 1990). The conductive heating combined with probable convective heating, associated with two intrusive episodes, would explain the complex set of multiple components of magnetization observed in this study.

The magnetization observed in the red beds of Hole $740 \mathrm{~A}$ is complex. The samples displaying the most stable, nearly univectoral magnetization make up roughly one-half of the sample population. The remaining samples display multicomponent magnetization. A clear case for remagnetization can be seen in many samples, despite the fact that no igneous rocks were recovered in the ODP drill hole.

From examining the rock samples after concluding the magnetic studies, it appears that there is a definite correlation between the rock magnetic characteristics and the lithology. The samples carrying a single component of magnetization are characterized by fine-grained clays and siltstones. The samples displaying multiple components of magnetization are the coarsest grained sandstones. The samples that have been remagnetized are heterogeneous samples showing burrows, leached areas associated with organic material, dendrites, and clasts. The heterogeneous areas (of contrasting grain size or composition) may be important pathways for the alteration of magnetic minerals associated with either diagenetic or deuteric alteration.

Thin-section studies of the magnetic carriers in the sediments are planned as part of continued cooperative studies by the authors. Some of the complications observed in the magnetization of these rocks may be related to multiple magnetizations associated with the formation of secondary minerals. At this time, magnetic behavior cannot be associated with specific magnetic minerals. Turner (this volume) described the overall depositional environment and petrography of these continental sediments but did not report the characteristics of the opaque minerals.

\section{Correlation}

The red beds from Hole 740A were found to have a lithology, sequence of rock types, thicknesses, magnetic properties, and thermal histories similar to those recorded in the literature for red beds in Antarctica. The similarity in rock characteristics indicates that the rocks drilled at Hole $740 \mathrm{~A}$ correspond to the Permian Amery Group red beds exposed at Beaver Lake in the nearby Prince Charles Mountains and are geologic equivalents of red beds exposed elsewhere in Antarctica.

\section{PALEOGEOGRAPHIC EVIDENCE}

Numerous paleogeographic reconstructions are available for Gondwanaland, which allows us to place general constraints on the position of Antarctica. Unfortunately, a reliable Permian paleomagnetic pole position is not available for Antarctica (Sakai and Funaki, 1988), in part because exposures of other rocks of this age are lacking due to the thick cap of ice over much of the Antarctic continent. The problem mostly, however, results from the widespread thermal remagnetization of Devonian-Permian-Triassic red beds throughout Antarctica. Prior land-based paleomagnetic studies of the Beacon Supergroup found remagnetization of the sediments consistent with the Jurassic directions of the intruding Ferrar dolerites (Turnbull, 1959; Bull et al., 1962; Funaki, 1983; Sakai and Funaki, 1988), which indicates pervasive (complete) remagnetization.

Most of the reconstructions of the continents rely heavily on the paleomagnetic data from Australia (McElhinney, 1973; McElhinney and Embleton, 1974). One of the most recent synthe- 

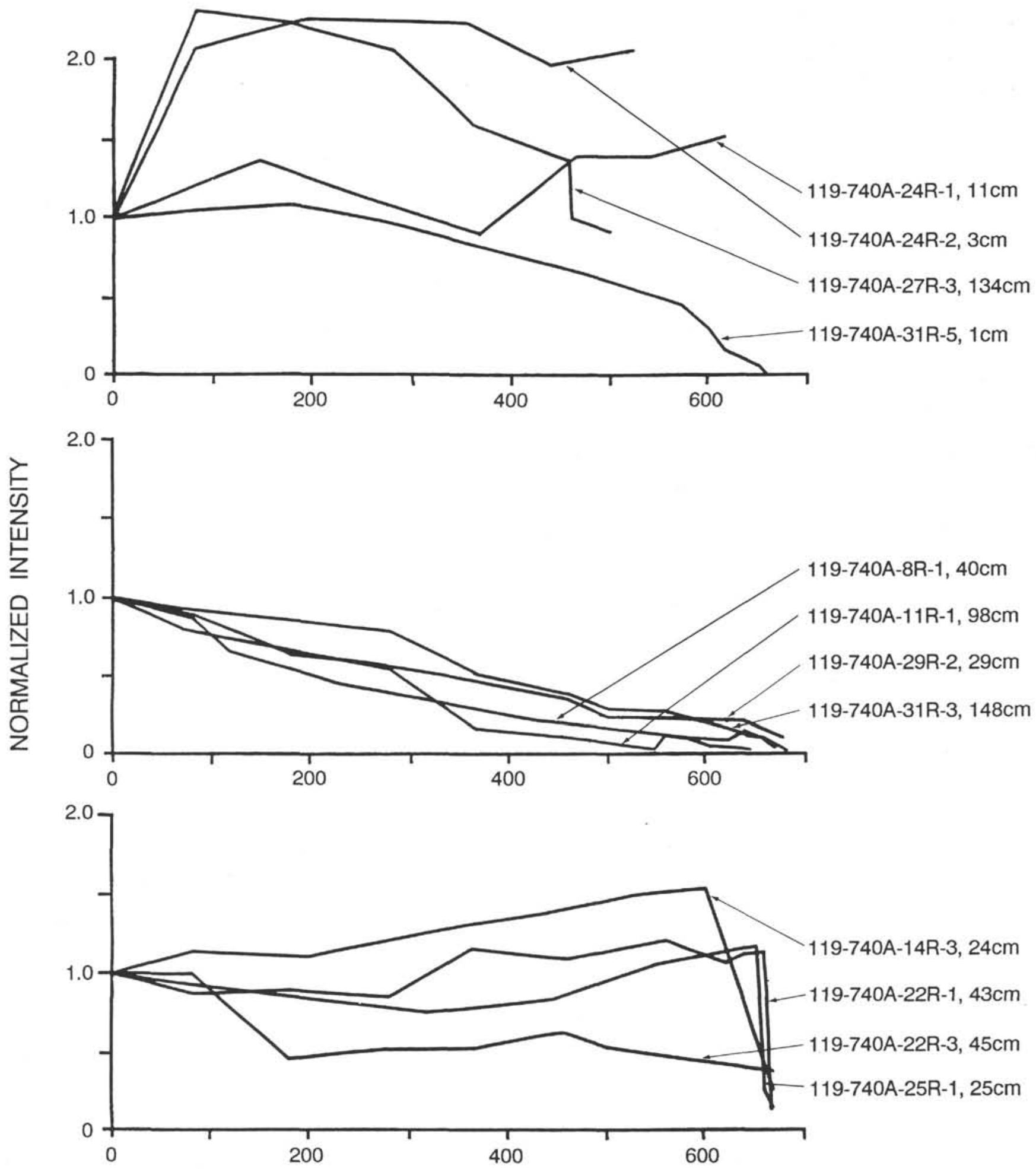

TEMPERATURE (Degrees C.)

Figure 8. Variation in thermal demagnetization curves for samples from Hole 740A. The top plot of thermal demagnetization curves for representative samples that show increases in intensity upon demagnetization shows that thermal remagnetization is present and that the superimposed magnetization commonly has the opposite polarity of the NRM. The central plot shows a variety of samples that experience gradual decay upon thermal demagnetization. The bottom plot shows further samples that display a wide range of demagnetization curves. The large spectrum of thermomagnetic behavior is consistent with both thermal remagnetization at varying distances for igneous bodies and convective heating by geothermal fluids, which would produce a range of thermal effects, rather than a uniform remagnetization. 
ses of data for plate tectonic reconstruction is that by Scotese (1976) as part of the programing for the Terra Mobilis computer projections of the motion of continents through time. The Permian reconstruction using this program (Fig. 9) places Antarctica at the South Pole. Other reconstructions have been proposed by Tarling (1972), Shields (1977), Morel and Irving (1978), Norton (1982), and Martin and Hartnady (1986), as well as others cited later in this text. Finally, reconstructions based upon faunal assemblages are also available (Stevens, 1985). In all of these reconstructions placement of the Antarctic continent is centered on the South Pole. Thus, the expected Permian inclination for Prydz Bay would be steep, on the order of $70^{\circ}$. Although steep NRM directions are observed, they are associated with a present Earth's field overprint. The thermal demagnetization experiments indicate that a magnetization of moderate to shallow inclination and both polarities is present, remagnetizing the rocks to varying degrees. This thermal overprint is most likely associated with widespread intrusions. Even where a single component magnetization has been isolated it is statistically identical to the inclinations reported for Jurassic intrusives in red beds elsewhere in Antarctica. This observation is consistent with a thermal remagnetization that would have obliterated the original Permian magnetization. Without structural corrections to reorient the samples, exact comparisons of the directions from rocks displaying single component magnetization and those displaying stable thermal remagnetizations cannot be made. Utilizing the data on hand, the mean inclinations from both appear to be the same.

Abundant evidence has been presented for a thermal remagnetization of the red beds collected at Hole 740A. Therefore, it is suggested that the thermal remagnetization of these sediments resulted from igneous intrusion within these sediments. The inclinations observed for the stable directions and for the secondary, thermally remagnetized component of magnetization cluster at $25^{\circ}$, yielding a paleolatitude of $15^{\circ}$. Using a blanket cor-

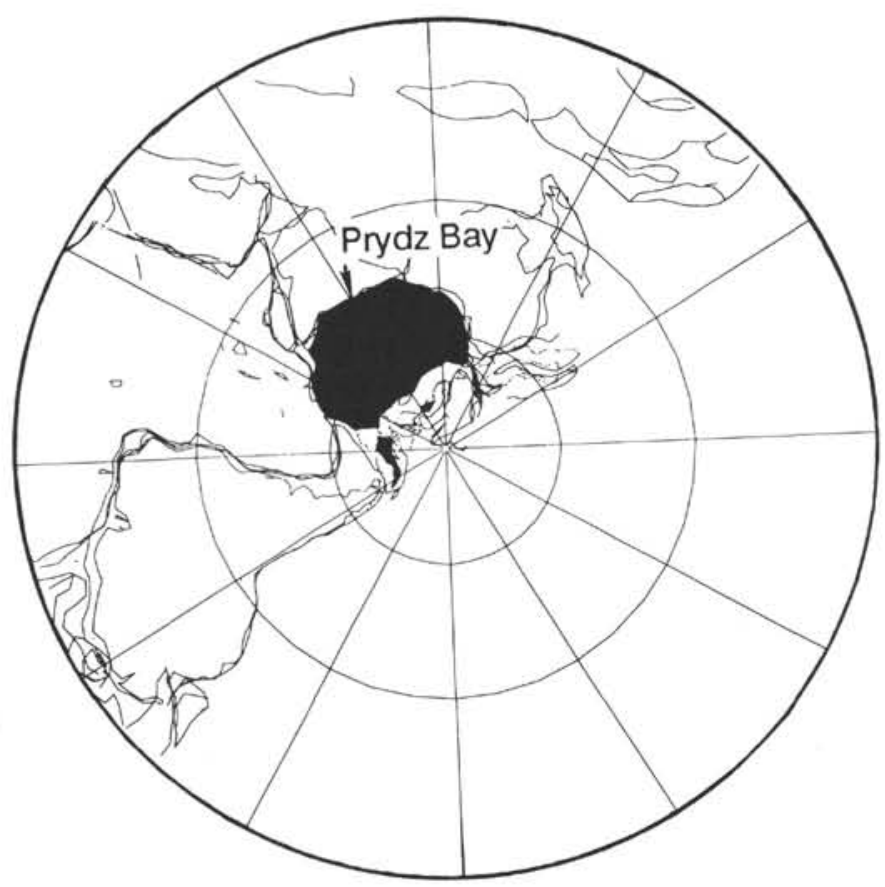

Figure 9. Polar projection showing the configuration of the continents during the Permian, courtesy of C. Scotese and associates. The Antarctic continent is shaded black. India is situated opposite Prydz Bay, Antarctica, prior to the opening of the Indian Ocean. rection of $15^{\circ}$ in lieu of actual tilt corrections, this would produce paleolatitudes of $30^{\circ}$ associated with the remagnetization of these sediments. This is consistent with the $30^{\circ}$ to $70^{\circ} \mathrm{S}$ latitude suggested for the Jurassic by Hamilton (1965), the paleomagnetic overprint associated with Jurassic intrusions (Sakai and Funaki, 1988), and faunal evidence that would place Prydz Bay at about $30^{\circ} \mathrm{S}$ latitude in the Jurassic (Stevens, 1985).

\section{DISTRIBUTION OF RED BEDS}

Paleogeographic studies of the distribution of red beds argue strongly that red beds formed at low to intermediate latitudes. Roughly $80 \%$ of the known red beds occur within $30^{\circ}$ of the equator, as shown in plots of occurrence vs. latitude (Tarling, 1983). The paleolatitudes observed for the Jurassic overprint directions are much more consistent with that range. The paleolatitude for the Permian red beds estimated from reconstructions, heavily weighted by the Australian data, appears anomalously high. Specialists in paleogeographic reconstructions (M. D. Matthews, pers. comm., 1989; Perlmutter and Matthews, 1989) believe that the formation of Permian red beds in the Antarctic would require unusual, longitudinal monsoon belts. If such monsoon belts existed during the Permian, evidence should be present elsewhere, for example, in southern Africa. At the present time, the high latitudes required by current Gondwanaland reconstructions require that red beds form at unusually high latitudes. This is particularly unusual considering the wide distribution of red beds in Antarctica. Frakes (1979) noted that evaporites usually associated with red beds are limited to less than $40^{\circ}$ in latitude, as shown by Drewey et al. (1974), except for a single occurrence in east central Africa at nearly $60^{\circ}$.

Paleoclimatic studies indicate that temperatures overall were cold in the Permian and glaciation was taking place in New Zealand and Australia (Frakes, 1979). The determination of a reliable Permian pole from Antarctica, at a site where thermal remagnetization has not taken place, would shed light on the occurrence of high-latitude red beds. The paradox of late Proterozoic glaciations at low latitudes is summarized by Chumakov and Elston (1989).

\section{RECONSTRUCTION OF ANTARCTICA AND INDIA}

Most Gondwanaland reconstructions place India opposite Prydz Bay, Antarctica (Smith and Hallam, 1970; Norton and Molnar, 1977; Morel and Irving, 1978; Markl, 1978; Norton and Sclater, 1979; Schmidt and Rowley, 1986). However, the position of India relative to Antarctica can vary widely. The Amery Ice Shelf (Prydz Bay) of eastern Antarctica is often placed in juxtaposition to the southeastern Indian coast (Smith et al., 1973; Craddock, 1975; Johnson et al., 1976). Acharyva (1979) pointed out that around the periphery of East Antarctica (between $10^{\circ} \mathrm{W}$ and $150^{\circ} \mathrm{E}$ ) the upper Permian Amery Group forms the only outcrop of the Beacon Supergroup (Elliot, 1975). Acharyva (1979) stated that the nature and thickness of the Gondwanaland Ice Shelf are distinctly different from those of the Mahanadi Valley in peninsular India. He argued that early Permian to Early Cretaceous age Gondwanaland sediments of the southeastern Indian coast, "especially those of the Manhanadi Valley, do not match with the Late Permian Amery Group," Beacon Supergroup, of eastern Antarctica.

Funaki et al. (in press) recently conducted paleomagnetic studies of Precambrian and Jurassic rocks from Sri Lanka. The new paleomagnetic results for Jurassic dolerites from Sri Lanka are consistent with Sri Lanka being positioned off LutzowHolm Bay, East Antarctica, in Jurassic time. In the reconstruction they suggested (Fig. 10), Prydz Bay is situated juxtaposed to the Mahanadi Graben. Based upon this paleomagnetic reconstruction the fit of India and Antarctica appears to be a very good match, despite the arguments of Acharyva (1979). 

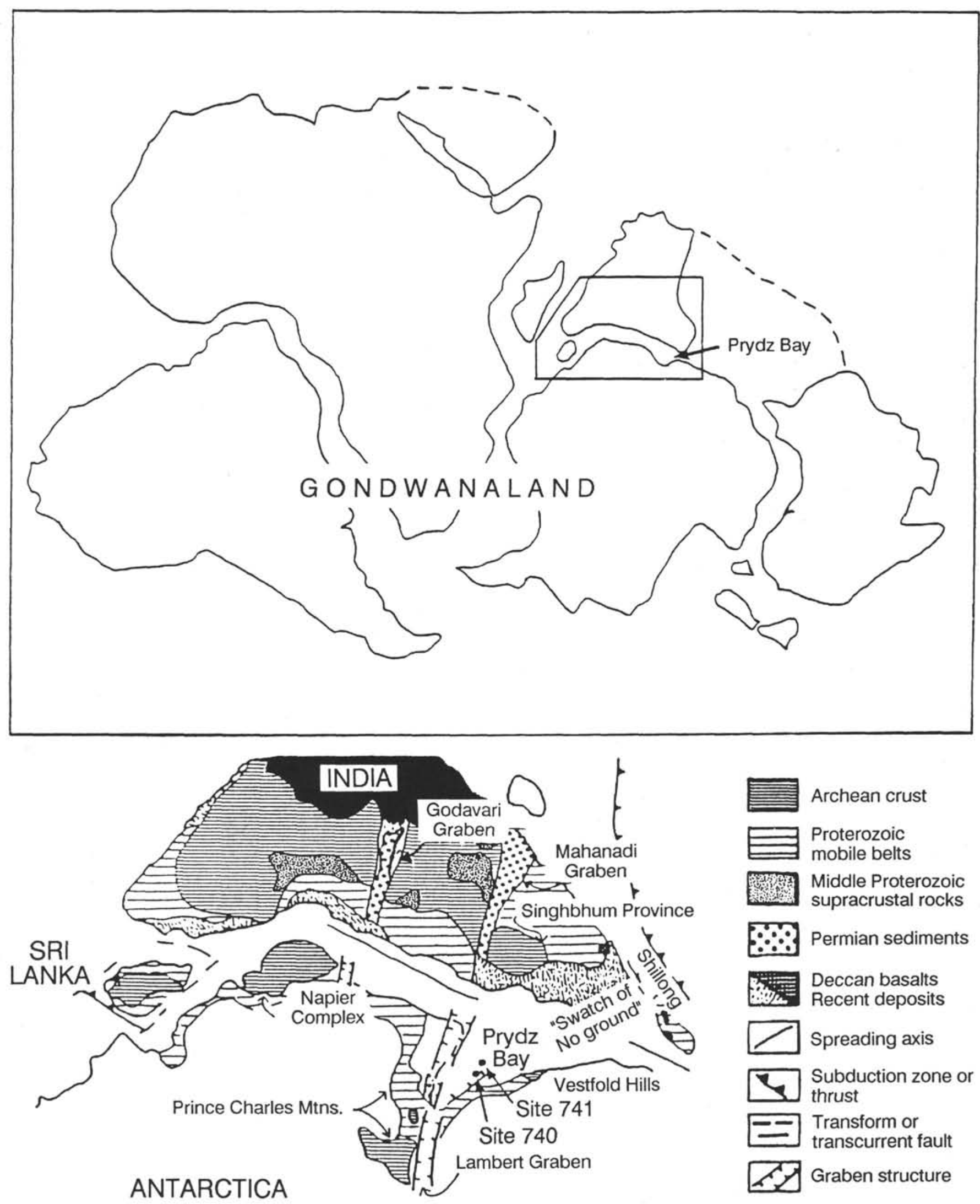

Figure 10. Reconstruction of Gondwanaland, based upon paleomagnetic results from Jurassic intrusives from Sri Lanka (Funaki et al., in press). In the detailed view, the sedimentary basin formed by the Mahanadi Graben is situated opposite Prydz Bay. Modified from Funaki et al. (in press). 


\section{SUMMARY}

The paleomagnetic studies of the red beds recovered from Hole $740 \mathrm{~A}$ indicate that the red beds display a strong overprint of the present Earth's field magnetization. This steeply inclined magnetization is resistant to alternating field demagnetization but responds to thermal treatment.

The thermal demagnetization experiments indicate that pervasive magnetic overprints in these samples are thermomagnetic in origin, causing varying degrees of remagnetization. The most frequently observed magnetization, after removal of overprinting magnetizations, is characterized by inclinations of $25^{\circ}$, which is consistent with similar results from studies of remagnetization by landbased Jurassic intrusions. The complex nature of remagnetization observed is consistent with conductive as well as convective heating of the sedimentary rocks associated with intrusive units. The magnetic characteristics of the red beds from Hole $740 \mathrm{~A}$ are also consistent with the magnetic characteristics of red beds exposed on the Antarctic continent, including a high critical blocking temperature and mixed polarity. The agreement in magnetic characteristics leads to the conclusion that the red beds collected at Hole $740 \mathrm{~A}$ are chronostratigraphic equivalents of red beds exposed on land. On the basis of lithology, stratigraphy, and rock magnetic similarities, the red bed sequence sampled at Hole $740 \mathrm{~A}$ is correlated with the Permian Amery Group of eastern Antarctica.

\section{ACKNOWLEDGMENTS}

The studies were carried out during a period when the first author was ill; consequently, the laboratory work and manuscript were delayed. I would like to thank USSAC for granting an extension for the grant support, which enabled me to complete this work. I would like to thank John Barron for his understanding of the delay and allowing a late submission of the manuscript. I would like to thank C. Scotese and associates for Figure 9 used in the manuscript, which they provided at an AGU meeting. I thank H. Sakai and M. Funaki for their discussions, which have assisted me in arriving at the conclusions outlined in this paper. And I thank M. Funaki for the preprint of his submitted manuscript, which allowed me to correlate this work with the reconstruction produced in that manuscript. I thank Don Elson for his review and very helpful suggestions for revision of the manuscript. I thank Charles Helsley for his assistance in the reconfiguration of the thermal demagnetization equipment for these experiments and Kenneth Helsley for his assistance with drafting. This is Hawaii Institute of Geophysics Contribution No. 2301.

\section{REFERENCES}

Acharyva, S. K., 1979. India and Southeast Asia in Gondwanaland fit. Tectonophysics, 56:261-276.

Barron, J., Larsen, B., et al., 1989. Proc. ODP, Init. Repts., 119: College Station, TX (Ocean Drilling Program).

Bennett, A.J.R., and Taylor, G. H., 1972. Coals from the vicinity of the Prince Charles Mountains, Antarctica. In Adie, R. J. (Ed.), Antarctic Geology and Geophysics: Oslo (Universitetsforlaget), 591-598.

Brown, E. L., 1981. Paleomagnetic estimates of temperatures reached in contact metamorphism. Geology, 9:112-116.

Bull, C., and Irving, E., 1960. The paleomagnetism of some hypabyssal intrusive rocks from south Victoria Land, Antarctica. Geophys. J., 3:211-214

Bull, C., Irving, E., and Willis, I., 1962. Further paleomagnetic results from South Victoria Land, Antarctica. Geophys. J. R. Astron. Soc., 6:320-336.

Christoffel, D. A., 1981. A hydrothermal model for resetting of paleomagnetic directions in Beacon sediments, Antarctica. N.Z. Geol. Soc. Conf., Hamilton. (Abstract)

Chumakov, N. M., and Elston, D. P., 1989. The paradox of late Proterozoic glaciations at low latitudes. Episodes, 12:115-120.
Craddock, C., 1975. Tectonic evolution of the Pacific margin of Gondwanaland. In Campbell, K.S.W. (Ed.), Gondwana Geology: Canberra (ANU Press), 609-618.

Crohn, P. W., 1959. A contribution to the geology and glaciology of the western part of Australian Antarctic Territory. Bull. Bur. Miner. Resour. Geol. Geophys. Aust., 52:1-103.

Drewey, G. E., Ramsey, A.T.S., and Smith, A. G., 1974. Climatically controlled sediments, the geomagnetic field, and trade wind belts in Phanerozoic time. J. Geol., 82:531-553.

Elliot, D., 1975. Gondwana basins of Antarctica. In Campbell, K.S.W. (Ed.), Gondwana Geology: Canberra (ANU Press), 493-536.

Frakes, L. A., 1979. Climates Throughout Geologic Time: Amsterdam (Elsevier).

Funaki, M., 1983. Paleomagnetic investigation of the Beacon Group in the McMurdo Sound region, Antarctica. Nankyoku Shiryo, 78:114.

Funaki, M., Yoshida, M., and Vitanage, P. W., in press. Paleomagnetic reconnaissance of Precambrian and Jurassic rocks of Sri Lanka. $J$. Sri Lanka Geol.

Grew, E. S., 1982. Geology of the Southern Prince Charles Mountains, East Antarctica. In Craddock, C., Loveless, J. K., Vierima, T. L., and Crawford, K. (Eds.), Antarctic Geoscience: Madison (Univ. of Wisconsin Press), 473-478.

Hamilton, W., 1965. Diabase sheets of the Taylor Glacier region, Victoria Land, Antarctica. Geol. Surv. Prof. Pap. U.S., 456-B:1-71.

Helgeson, J., 1981. Magnetostratigraphy of the exposed lava section east of the IRDP drill hole in Reydarfjordur, eastern Iceland. $J$. Geophys. Res., 87:6396-6404.

Hofman, J., 1982. Main tectonic features and development of the Southern Prince Charles Mountains, East Antarctica. In Craddock, C., Loveless, J. K., Vierima, T. L., and Crawford, K. (Eds.), Antarctic Geoscience: Madison (Univ. of Wisconsin Press), 479-487.

Johnson, B. D., Powell, C. McA., and Veevers, J. J., 1976. Spreading history of the eastern Indian Ocean and Greater India's northward flight from Antarctica and Australia. Geol. Soc. Am. Bull., 87: $1560-1566$.

Kemp, E. M., 1972. Recycled palynomorphs in continental shelf sediments from Antarctica. Antarct. J. U.S., 7:190-191.

1973. Permian flora from the Beaver Lake Area, Prince Charles Mountains, Antarctica, I. Palynological examination of samples. Bull. Bur. Miner. Resour. Geol. Geophys. Aust., 126:7-12.

Leng, E. H., 1955. The magnetic properties of ore minerals [Ph.D. dissert.]. Univ. of London.

Markl, R. G., 1978. Further evidence for the Early Cretaceous breakup of Gondwanaland off southwestern Australia. Mar. Geol., 26:4148.

Martin, A. K., and Hartnady, C.J.H., 1986. Plate tectonic development of the southwest Indian Ocean: a revised reconstruction of East Antarctica and Africa. J. Geophys. Res., 91:4767-4786.

McElhinney, M. W., 1973. Paleomagnetism and Plate Tectonics: Cambridge (Cambridge Univ. Press).

McElhinney, M. W., and Embleton, B.J.J., 1974. Australian palaeomagnetism and the Phanerozoic plate tectonics of eastern Gondwana. Tectonophysics, 22:1-29.

McIntosh, W. C., Kyle, P. R., Cherry, E. M., and Noltimier, H. C., 1982. Paleomagnetic results from the Kirkpatrick Basalt Group, Victoria Land. Antarct. J. U.S. Rev., 17:20-22.

McKelvey, B. C., and Stephenson, N.C.N., 1990. A geological reconnaissance of the Radok Lake area, Amery Oasis, Prince Charles Mountains. Antarct. Sci., 2:53-66.

Mond, A., 1972. Permian sediments of the Beaver Lake area, Prince Charles Mountains. In Adie, R. J. (Ed.), Antarctic Geology and Geophysics: Oslo (Universitetsforlaget), 585-589.

Morel, P., and Irving, E., 1978. Tentative paleocontinental maps for the early Phanerozoic and Proterozoic. J. Geol., 86:535-561.

Norton, I., and Molnar, P., 1977. Implications of a revised fit between Australia and Antarctica for the evolution of the eastern Indian Ocean. Nature, 267:338-340.

Norton, I. O., 1982. Paleomotion between Africa, South America, and Antarctica, and implications for the Antarctic Peninsula. In Craddock, C., Loveless, J. K., Vierima, T. L., and Crawford, K. (Eds.), Antarctic Geoscience: Madison (Univ. of Wisconsin Press): 81-590.

Norton, I. O., and Sclater, J. G., 1979. A model for the evolution of the Indian Ocean and the breakup of Gondwanaland. J. Geophys. Res., 84:6803-6830. 
AMERY GROUP RED BEDS IN PRYDZ BAY

Peddle, N. W., and Zunde, A. K., 1988, The Magnetic Field of the Earth -1985: U.S. Dep. Inter., Map Gp-987-1.

Perlmutter, M. A., and Matthews, M. D., 1989. Global cyclostratigraphy: effects of the timing of sediment delivery to continental margins relative to sea level. Abstract Volume, AGU Chapman Conference on Long-Term Sea Level Changes, Snowbird, Utah. (Abstract)

Ravish, M. G., and Fedorov, L. V., 1982. Geologic structure of MacRobertson Land and Princess Elizabeth Land, East Antarctica. In Craddock, C., Loveless, J. K., Vierima, J. L., and Crawford, K. (Eds.), Antarctic Geoscience: Madison (Univ. of Wisconsin Press), 499-504.

Ravish, G. M., Gr, Yu. G., Dibner, A. F., and Lobanova, O. V., 1977. Stratigrafia verknepaleozoiskikh uglenosuykh otlozhenii Vostochnoi Antarkidy (rain ozera river) [The stratigraphy of upper Paleozoic coal measures (Beaver Lake area, East Antarctica)]. Antarktika, Doklady Nom., 16:62-75.

Ruker, R. A., 1963. Geological reconnaissance in Enderby Land and the southern Prince Charles Mountains, Antarctica. Rec. Bur. Miner. Resour. Geol. Geophys. Aust., Rep. 1963/154. [Unpubl.]

Sakai, H., and Funaki, M., 1988. Paleomagnetic study of the Beacon Supergroup in Antarctica: remagnetization in the Jurassic time. Proc. NIPR Symp. Antarct. Geosci., 2:46-54.

Schmidt, D. L., and Rowley, P. D., 1986. Continental rifting and transform faulting along the Jurassic Transantarctic Rift, Antarctica. Tectonics, 5:279-291.

Scotese, C. R., 1976. A continental drift "flip-book." Computers Geosci., 2:113-116.

Shields, O., 1977. A Gondwanaland reconstruction for the Indian Ocean. J. Geol., 85:236-242.
Smith, A., and Hallam, A., 1970. The fit of the southern continents. Nature, 225:139-144.

Smith, A. G., Biden, J. C., and Dewey, G. E., 1973. Phanerozoic world maps. In Hughes, N. F. (Ed.), Organisms and Continents Through Time. Paleontology, Spec. Pap., 12:1-42.

Stage, H.M.J., 1985. The structure and origin of Prydz Bay and MacRobertson Shelf, East Antarctica. Tectonophysics, 114:315-340.

Stevens, G., 1985. Lands In Collision: Discovering New Zealand's Past Geography: Wellington (Sci. Information Publ. Center), 44-59.

Taring, D. H., 1972. Another Gondwanaland. Nature, 238:92-93. , 1983. Palaeomagnetism, Principles and Applications in Geology, Geophysics and Archaeology: New York (Chapman and Hall). Tingly, R. J., 1972. Geological work in Antarctica, 1971. Rec. Bur. Miner. Resour. Geol. Geophys. Austra., Rep. No. 1973/132:1-49. [Unpubl.]

Truswell, E. M., 1982. Palynology of seafloor samples collected by the 1911-14 Australian Antarctic Expedition: implications for the geology of coastal East Antarctica. J. Geol. Soc. Aust., 29:343-356.

Turnbull, G., 1959. Some paleomagnetic measurements in Antarctica. Arctic, 12:151-157.

White, M. E., 1962. Permian plant remains from Mount Rymill, Antarctic. In Report of 1961. Plant fossil collections. Rec. Bur. Miner. Resour. Geol. Geophys. Aust., 1962/114:13-18. [Unpubl.]

1973. Permian flora from the Beaver Lake area, Prince Chares Mountains, Antarctica. 2: Plant fossils. Bull. Bur. Miner. Resour. Geol. Geophys. Aust., 126:13-18.

Date of initial receipt: 5 February 1990

Date of acceptance: 22 June 1990

Ms 119B-148

809 